\title{
The Sources of Value
}

"Let it however be observed that though the words human nature are to be explained, yet the real question of this discourse is not concerning the meaning of words."

Bishop Joseph BUTLER

Fifteen Sermons upon Human Nature, Sermon II 



\section{THE SOURCES OF}

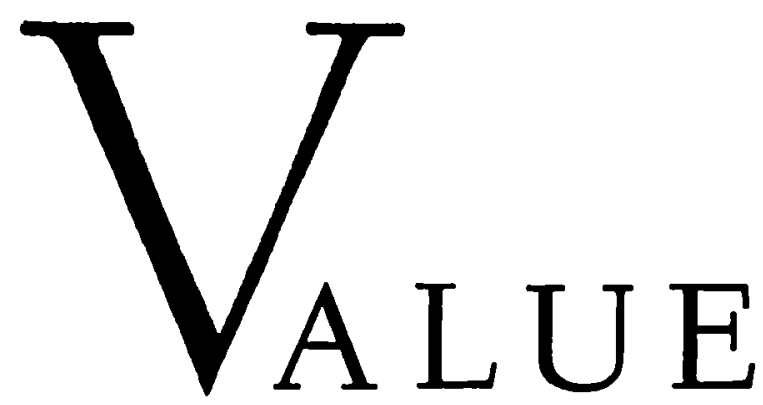

\section{Stephen C. Pepper}

UNIVERSITY OF CALIFORNIA PRESS

Berkeley, Los Angeles, London 
University of California Press

Berkeley and Los Angeles, California

Untversity of California Press, Ltd.

London, England

1958 by The Regents of the University of California

Second printing, 1970

ISBN 0-520-01798-6

Library of Congress Catalog Card Number: 58-8657

Printed in the United States of America

Designed by Adrian Wilson 
To

the chief source of my personal values my wife Ellen 
